\title{
Effect of Seed Treatment on Incidence and Severity of Garlic White Rot (Sclerotium cepivorum Berk) in the Highland Area of South Tigray, North Ethiopia
}

\author{
Harnet Abrha $^{1 *}$, Alem Gebretsadik ${ }^{2}$, Girmay Tesfay ${ }^{3}$ and Girmay Gebresamuel ${ }^{4}$ \\ ${ }^{1}$ Tigray Agricultural Research Institute, Alamata Agricultural Research Center, P.O.Box-56 Alamata, Ethiopia \\ ${ }^{2}$ Capacity Building for Scaling up of Evidence-Based Best Practices in Agricultural Production in Ethiopia (CASCAPE) project, Mekelle, Ethiopia \\ ${ }^{3}$ Department of Land Resources Management and Environmental Protection, Mekelle University, Ethiopia \\ ${ }^{4}$ Department of Natural Resources Economics and Management, Mekelle University, Ethiopia
}

\begin{abstract}
A participatory evaluation of integrated white rot management was conducted for two years during the 2013 and 2014 main cropping seasons (Julys-October) in Emba-Alaje and Enda-Mokoni Woredas of South Tigray. The sites selected for the trial were potential for garlic production and many farmers used this crop as main source of income. However, the productivity of the crop is declining from time to time due to white rot infestation. Hence, this study was conducted to evaluate hot water treatment and chemical application on controlling white rot infestation. During the first year, three treatments were used for the experiment: chemical treatment (Apron star 42 WS), hot water treatment at $46^{\circ} \mathrm{C}$ and farmers practice (control). During the second demonstration year additional treatment hot treatment plus chemical treatment included. The first year results indicated that lowest white rot incidence (25\%) and number of cloves per hectare (2670) infected by white rot was recorded from hot water treated plots followed by chemical treatment ( $29 \%$ incidence) and (4240 infected cloves) per hectare. White rot incidence and number of plants per hectare infected by white rot was very high in the control plots as exhibited by $45 \%$ and 7910 plants, respectively. Significantly higher marketable yield (126.09 qt/ha) was obtained from hot water treated plots, while the lowest marketable yield (96.576 qt/ha) was obtained from the control or farmers practice plots. About $30.5 \%$ yield advantage was obtained from hot water treated plots compared to the control plot. The same result was also recorded during the second year demonstration. In Ayba and Atsela Kebeles the highest marketable yield and low white rot incidence and severity were recorded from hot water treated plots. Hot water treatment has also received higher acceptances and was ranked first by the farmer's participated in the research for its low cost and higher response Unlike the two Kebeles, incidence of white rot in Simret Kebele was $100 \%$ in all treatments, however hot water treatment preferred by participant farmers by its accessibility. Therefore, from the result we can conclude that based on the accessibility, environmental benefits and farmer's preferences hot water treatment is promising practice for white rot treatment in the intervention Kebeles.
\end{abstract}

Keywords: Apron star; Farmers practice; Garlic; Hot water; White rot

\section{Introduction}

Garlic (Allium sativum) belongs to the Alliaceae family, in the same family with onions, shallots and leeks. Garlic is one of the most important crops widely cultivated throughout the world including Ethiopia. It is the second most widely cultivated Allium species next to onion [1]. In Ethiopia, a total of 10,690.41 ha of land was under garlic production during the 2011 main cropping season, taking up about $6.64 \%$ of land area covered by all vegetable crops at country level and yielding about $128,440.94$ tons of those cultivated by small scale farmers, contributing about $7.42 \%$ to the total country level vegetable crop production [2].

Onion and garlic white rot caused by Sclerotium cepivorum is a major production threat of garlic and onion in the Tigray Regional state of Ethiopia. During favorable weather condition and when susceptible varieties are in the production system, the disease can cause $100 \%$ yield loss [3]. The highland areas of south Tigray are potential areas for cultivation of garlic, many farmers in the particular zone widely cultivate this crop and used as the main source of income [4]. However, the productivity of the crop is declining from time to time and farmers are forced to lose the profit that they used to earn from sale of the produce of this commodity. Because of this, farmers are discouraged to grow Garlic. There is no resistant variety available in Ethiopia to tackle the disease. However, Alamata agriculture research center was conducting adaption trail of different garlic varieties including a local check namely Bora local. The result indicated that, the highest bulb yield (62.79 and $27.90 \mathrm{qt} / \mathrm{ha}$ ) was recorded from Bora local at Fala and Ayba Kebeles, respectively and it was moderately white rot resistance as compared to the released varieties.

Fungicides are among the most effective options for white rot management. Systemic as well as non-systemic fungicides significantly reduced incidence of white rot, its progress rate, severity, and thereby improved the yield of the crop. It has been reported that the use of procymidone as seed and soil treatment reduced disease incidence up to $75-95 \%$ [5]. The fungicide apron star $42 \mathrm{WS}$ is the most effective

*Corresponding author: Harnet Abrha, Tigray Agricultural Research Institute, Alamata Agricultural Research Center, P.O.Box-56 Alamata, Ethiopia, Tel: +251-34 440 2801; E-mail: hany7mn@gmail.com

Received July 10, 2015; Accepted August 21, 2015; Published August 25, 2015

Citation: Abrha H, Gebretsadik A, Tesfay G, Gebresamuel G (2015) Effect of Seed Treatment on Incidence and Severity of Garlic White Rot (Sclerotium cepivorum Berk) in the Highland Area of South Tigray, North Ethiopia. J Plant Pathol Microb 6: 294. doi:10.4172/2157-7471.1000294

Copyright: ( 2015 Abrha $\mathrm{H}$, et al. This is an open-access article distributed under the terms of the Creative Commons Attribution License, which permits unrestricted use, distribution, and reproduction in any medium, provided the original author and source are credited. 
means of controlling many soil and seed borne fungal diseases. It is also effective in controlling white rot of garlic under Ethiopian condition and is ecologically safe since it is used as clove or seed treatment. Alamata Agriculture Research Centre annual report also indicated that onion seed treated by apron star showed $12 \%$ yield increment under farmers' field than the untreated seed at Ofla Woreda in Zata Kebele [6].

Cultural management practices like avoidance and sanitation are recommended. Cull bulbs, litter, and soil should not be moved from infested to non-infested fields. Equipment should be cleaned before moving from one field to another. The most effective way to avoid introducing the disease is to plant only clean stock from known origins that have no history of white rot. However, the fungus is vulnerable at temperatures above $46^{\circ} \mathrm{C}$, thus dipping seed of garlic in hot water before planting can greatly reduce the amount of pathogen and is a good preventative measure, although it may not completely eradicate the fungus [7]. However, temperatures above $49^{\circ} \mathrm{C}$ may kill the garlic, so careful temperature control is essential. This study was conducted to evaluate the performance of hot water and apron star treatment on controlling white rot infestation of local garlic variety managed by typical smallholder farmers. This research was intended to provide farmers with alternative way of dealing white root rot disease using local resource.

\section{Objective}

To enhance production and productivity of garlic through integrated management of white rot disease.

\section{Materials and Methods}

\section{Area description}

Demonstration was conducted in 3 major garlic growing highland Kebeles of Emba-Alaje and Enda Mekoni Woredas of southern zone of Tigray region. The Kebeles included were Atsela and Ayba from Emba-Alaje, and Simret from Enda Mekoni Woredas. Atsela, Ayba and Simret, Kebeles are located at $1255.733^{\prime} \mathrm{N}$ and $039^{\circ} 31.606^{\prime} \mathrm{E}$; $12^{\circ} 53.495^{\prime} \mathrm{N}$ and $039^{\circ} 32.120^{\prime}$; and $12^{\circ} 43.576^{\prime} \mathrm{N}$ and $039^{\circ} 30.355^{\prime} \mathrm{E}$, respectively. The Kebeles have altitudes of 2463, 2724, and 2509 m.a.s.l, respectively. The intervention Kebeles experience a bi-modal type of rainfall and the mean annual rainfall ranges from 300 to $1600 \mathrm{~mm}$. Eutric cambisols with eutric regosols/lithosols are found in Emba-Alaje and chromic vertisols with eutric cambisols is found in Enda Mekoni Woreda. Site selection was made based on the potential of the area for garlic production and availability of white rot disease.

\section{Experimental design and procedure}

The trial was conducted during 2013 and 2014 cropping seasons. A total of 30 farmers (10 in first year and 20 in second years) participated on the demonstration considering availability of the white rot disease on specific farm and farmer's willingness to participate in demonstration. Participant farmers in each Kebele were considered as replication and all treatments were applied per farm. Each participating farmer allocated an area of $10 \mathrm{~m} \times 31 \mathrm{~m}$ and $4.8 \mathrm{~m} \times 21.5 \mathrm{~m}$ in first and second years, respectively. Well sprouted Bora local garlic variety was used as planting material for the demonstration. Management of the farms was based on agreed recommended agronomic practices.

\section{Treatments used in the experiments}

The treatments used in the experiments were:

Treatment one: Chemical/apron star treatment: The required amount of cloves to be treated was weighed as rate of $600 \mathrm{~kg} / \mathrm{ha}$ and poured in wet table powders of Apron Star $42 \mathrm{WS}$ with a rate of $3 \mathrm{gm}$ apron star and $10 \mathrm{ml}$ water for one $\mathrm{kg}$ garlic seed. Chemical treated garlic clove was planted with spacing of $10 \mathrm{~cm}$ between plants and $30 \mathrm{~cm}$ between rows. Inorganic fertilizers, diammonium phosphate (DAP) and urea were applied at the rate of $200 \mathrm{~kg} / \mathrm{ha}$ DAP and 150 $\mathrm{kg} / \mathrm{ha}$ Urea. The whole amount of phosphorus fertilizer was applied at planting, whereas half rate of urea was applied during planting and remaining was applied 30-45 days after planting.

Treatment two: Hot water treatment: Garlic cloves weighted as rate of $600 \mathrm{~kg} / \mathrm{ha}$ and dipped in hot water at $46^{\circ} \mathrm{C}$ for 20 minutes. The treated garlic clove was planted with spacing of $10 \mathrm{~cm}$ between plants and $30 \mathrm{~cm}$ between rows. Inorganic fertilizers, diammonium phosphate (DAP) and urea were applied at the rate of $200 \mathrm{~kg} / \mathrm{ha}$ DAP and 150 $\mathrm{kg} / \mathrm{ha}$ Urea. The whole amount of phosphorus fertilizer was applied at planting, whereas half rate of urea was applied during planting and remaining was applied 30-45 days after planting.

Treatment three: Hot water followed by chemical treatment: First garlic cloves was weighted in the rate of $600 \mathrm{~kg} / \mathrm{ha}$ and dipped in hot water at $46^{\circ} \mathrm{C}$ for 20 minutes followed by poured in wet table powders of Apron Star 42 WS with a rate of $3 \mathrm{gm}$ apron star and 10 $\mathrm{ml}$ water for $1 \mathrm{~kg}$ garlic seed. Hot water and chemical treated garlic clove was planted with spacing of $10 \mathrm{~cm}$ between plants and $30 \mathrm{~cm}$ between rows. Inorganic fertilizers, diammonium phosphate (DAP) and urea were applied at the rate of $200 \mathrm{~kg} / \mathrm{ha} \mathrm{DAP}$ and $150 \mathrm{~kg} / \mathrm{ha}$ Urea. The whole amount of phosphorus fertilizer was applied at planting, whereas half rate of urea was applied during planting and remaining was applied 30-45 days after planting.

Treatment four: Control plot managed based on farmer's practices and the other management practices (fertilizer, sanitation, irrigation interval, weeding and cultivation) were applied equally according to the recommendations for all treatments.

\section{Data collection and statistical analysis}

Disease, yield and yield components data like, white rot and rust severity and incidence, plant height, leaf number, number of bulbs infected and non-infected by white rot, infected/unmarketable yield and health/marketable yield were collected according to their standard procedure. The different traits were recorded at different growth stages of the crop and analyzed using GenStat version 16 computer software.

\section{Results and Discussion}

\section{White root rot and rust intensity}

During the first year, as compared to the control plots, incidence and severity of white root rot was very low on hot water treated plots followed by chemical treated plots. The incidence of white rot was $45 \%$ in farmers/control plots and the number of plants per hectare infected by white root rot was 7910 . In contrast, incidence and number of plants infected by white root rot was $25 \%$ and 2670 for hot water treated plots and $29 \%$ and 4240 for apron star treated plots, respectively. These values are very low compared what was found under control plots demonstrating both management practices are promising for the area. This result were in line with the findings of Davis [8] who revealed that dipping garlic clove in hot water will greatly reduce the amount of pathogen and is a good preventative measure although it may not completely eradicate the fungus (Figure 1).

In the case of rust occurrence, it was observed on all plots but the intensity was higher on farmer's practises plots. Incidence of rust 
Citation: Abrha H, Gebretsadik A, Tesfay G, Gebresamuel G (2015) Effect of Seed Treatment on Incidence and Severity of Garlic White Rot (Sclerotium cepivorum Berk) in the Highland Area of South Tigray, North Ethiopia. J Plant Pathol Microb 6: 294. doi:10.4172/2157-7471.1000294

Page 3 of 5

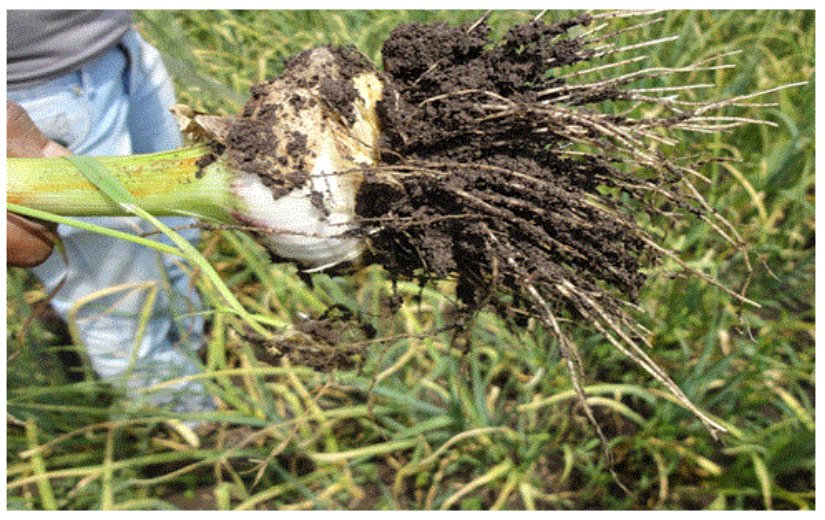

Figure 1: Healthy clove harvested from hot water treated plots.

was low on hot water treated plots followed by chemical treated plots. However, less severity was observed on chemical treated plot (Table 1). The incidence of rust on the chemical treated and hot water treated plots was 92 and 84 percent, respectively with a severity of 25 and $31 \%$ on chemical treated and hot water treated plots, respectively. On the other hand, incidence and severity of rust on the control plots were 97 and $51 \%$, respectively (Figure 2).

During the second production season, intensities of white rot and rust were varied from location to location depending on the climatic condition of each area (Table 2). In line with this, Pinto et al. [9] also reported incidence and severity of white rot will depend both on the state of development of the host and on the suitability of soil conditions (mainly temperature) for the development of the pathogen and the host root system and, therefore, the production of exudates. A maximum (100\%) possible rust incidence was noted in Ayba and Simret Kebeles for all the treatment combinations at both locations. This indicated that rust was important for garlic crop as the treatments used have no effect on the incidence of the disease. Significant difference of disease severity was noted at Ayba but not at Simret Kebele. Hot water treatment has scored the highest severity percentage (58.21\%), whereas the lowest was for chemical treatment at Ayba Kebele. In Simret Kebele, the highest rust severity percentage was recorded on the farmers plot. Same result was also observed from last year demonstration, in Ayba Kebele where less severity of rust was recorded on chemical treated plot. Even though severity of rust disease was higher in hot-water treated plots in Ayba Kebele, the availability of disease has not significantly affected yield of garlic, because occurrence was started at the crop maturity stage. The incidence of white rot was significantly different among treatments at Ayba Kebele but not-significant at Atsela and Simret Kebeles and it has sustained $100 \%$ incidence in Simret Kebele. Significantly higher incidence was noted from farmers practice plots than other treatments at Ayba and higher numeric increase at Atsela. The severity of white rot was non-significant at all locations for the treatments. Reduced severity was noted from hot water plus chemical treated plots but not significantly different with hot water treated plots. However, at Simret Kebele the lowest severity was recorded from plots planted to chemical treated cloves. Delgadillo et al. [10] also reported that reduction of Allium white rot severity has been achieved by use of fungicides. The two year demonstration result revealed that the two diseases (white rot and rust) were major concern, as it is expected to have a major economic significance in the Tigray highlands, especially with poor crop management practices.

\section{Plant height $(\mathrm{cm})$ and leaf number per plant}

The highest and significantly different plant height and leaf number per plant $(80.31 \mathrm{~cm}$ and 10.76$)$ was recorded from hot water treated plots followed by chemical treated plots for the values of $78.38 \mathrm{~cm}$ and 10.47 plant height and leaf number per plant, respectively. In contrast the lowest and significantly different plant height and average leaf number per plant $(76.68 \mathrm{~cm}$ and 9.88$)$ also recorded from the control plots (farmers practise plots), respectively (Table 3 ).

\section{Garlic bulb yield (qt/ha)}

In the first year demonstration, statistically higher health (marketable) yield (126.09 qt/ha) was obtained from hot water treated plots followed by chemical treated plots for the value of $111.761 \mathrm{qt} /$ ha. In contrary, significantly lower health/ marketable yield (96.576 qt/ ha) was recorded from the farmers practice/control plots. On the other hand, control plots had significantly higher rate of infested bulb yield by white rot ( $34.707 \mathrm{qt} / \mathrm{ha})$, while the lowest was recorded from hot water and chemical treated plots 16.587 and $21.505 \mathrm{qt} /$ ha respectively. A total of $30.5 \%$ yield advantage was obtained from hot water treated plot than farmers practice plot in health/marketable yield situations.

The 2014 production season result obtained on yield data is presented in Table 4 . The present result indicated that the highest health bulb yield (87.08 qt/ha) in Ayba Kebele was obtained from chemical plus hot water treated plots followed by hot water treated plots which recorded a mean marketable yield of (77.46 qt/ha). However, in the case of Atsela Kebele numerically the highest health yield (57.93 qt/ha) was recorded from hot water treated plots followed

\begin{tabular}{|c|c|c|c|c|}
\hline Treatments & $\begin{array}{c}\text { Number of } \\
\text { Plants/ha infected } \\
\text { by white rot }\end{array}$ & $\begin{array}{c}\text { White root rot } \\
\text { Incidence (\%) }\end{array}$ & $\begin{array}{c}\text { Rust } \\
\text { Severity } \\
\text { (\%) }\end{array}$ & $\begin{array}{c}\text { Rust } \\
\text { Incidence } \\
\text { (\%) }\end{array}$ \\
\hline $\begin{array}{c}\text { Apron Star } \\
\text { Treatment }\end{array}$ & $4240^{\mathrm{b}}$ & $29^{\mathrm{b}}$ & $25^{\mathrm{c}}$ & $92^{\mathrm{a}}$ \\
\hline $\begin{array}{c}\text { Hot Water } \\
\text { Treatment }\end{array}$ & $2670^{\mathrm{b}}$ & $25^{\mathrm{b}}$ & $31^{\mathrm{b}}$ & $84^{\mathrm{a}}$ \\
\hline Farmers Practice & $7910^{\mathrm{a}}$ & $45^{\mathrm{a}}$ & $51^{\mathrm{a}}$ & $97^{\mathrm{a}}$ \\
\hline $\begin{array}{c}\text { LSD (5\%) } \\
\text { CV (\%) }\end{array}$ & $\begin{array}{c}2310.5 \\
49\end{array}$ & 6.12 & 5.12 & 13.54 \\
15
\end{tabular}

*Values connected by the same letter across a column are not statistically different at $5 \%$ significant level

Table 1: Effect of seed treatment on white rot and rust intensity of garlic in 2013 production season.

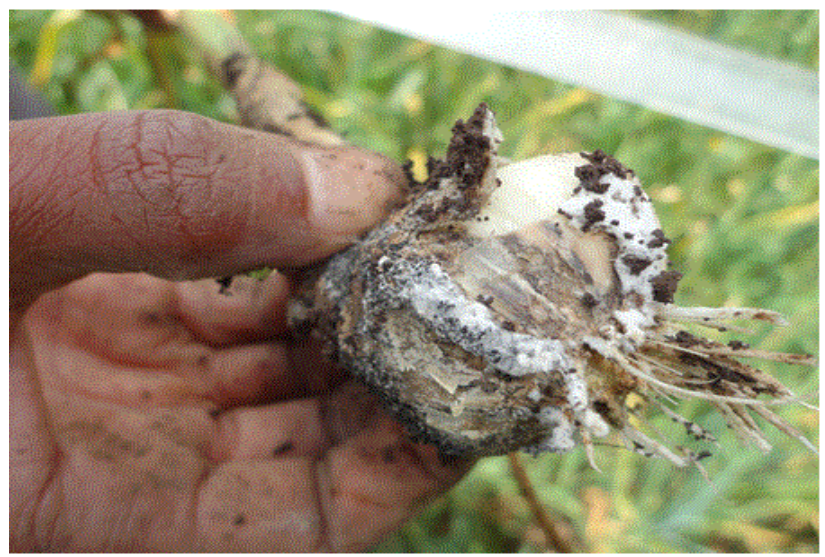

Figure 2: Infected clove by white rot from control plots. 


\begin{tabular}{|c|c|c|c|c|c|c|c|c|c|c|}
\hline \multirow{4}{*}{ Treatments } & \multicolumn{10}{|c|}{ Kebeles (demonstration sites) } \\
\hline & \multicolumn{4}{|c|}{ Ayba } & \multirow{2}{*}{\multicolumn{2}{|c|}{$\begin{array}{c}\text { Atsela } \\
\text { White root rot }\end{array}$}} & \multicolumn{4}{|c|}{ Simret } \\
\hline & \multicolumn{2}{|c|}{ Rust } & White root rot & & & & \multicolumn{2}{|c|}{ Rust } & \multicolumn{2}{|c|}{ White root rot } \\
\hline & INC (\%) & SEV (\%) & INC (\%) & SEV $(\%)$ & INC (\%) & SEV (\%) & INC (\%) & SEV $(\%)$ & INC (\%) & SEV (\%) \\
\hline Chemical & 100 & $41.96^{b}$ & $3.91^{\mathrm{b}}$ & $31.1^{\mathrm{a}}$ & $16.28^{a}$ & $10.2^{\mathrm{a}}$ & 100 & $10^{a}$ & 100 & $29.17^{a}$ \\
\hline Hot water & 100 & $58.21^{\mathrm{a}}$ & $3.72^{\mathrm{b}}$ & $28.4^{a}$ & $15.09^{a}$ & $9.1^{\mathrm{a}}$ & 100 & $8.3^{\mathrm{a}}$ & 100 & $50.83^{a}$ \\
\hline Hot water+chemical & 100 & $46.07^{\mathrm{ab}}$ & $3.32^{b}$ & $22.6^{a}$ & $14.61^{\mathrm{a}}$ & $9.0^{\mathrm{a}}$ & 100 & $7^{\mathrm{a}}$ & 100 & $42.50^{\mathrm{a}}$ \\
\hline Control & 100 & $51.71^{\mathrm{ab}}$ & $20.59^{a}$ & $33.7^{\mathrm{a}}$ & $18.30^{\mathrm{a}}$ & $10.3^{a}$ & 100 & $15^{\mathrm{a}}$ & 100 & $33.33^{a}$ \\
\hline LSD & 100 & 13.51 & 10.29 & 15.43 & 7.21 & 5.139 & 100 & 9.67 & 100 & 31.38 \\
\hline $\mathrm{CV}$ & 24.3 & 24.3 & 18 & 33.4 & 32.6 & 28.6 & 28 & 28 & 23.3 & 23.3 \\
\hline
\end{tabular}

Table 2: Effect of seed treatment on white rot and rust intensities of garlic in Atsela, Ayba and Simret Kebeles in 2014 production season. *Values connected by the same letter across a column are not statistically different at $5 \%$ significant level.

\begin{tabular}{|c|c|c|c|c|}
\hline Treatments & Average plant Height (cm) & Average leaf Number per Plant & Marketable (health) yield qt/ha & Unmarketable (infected by white rot) yield qt \\
\hline Chemical treatment & $78.38^{\mathrm{b}}$ & $10.47^{\mathrm{b}}$ & $111.761^{\mathrm{b}}$ \\
\hline Hot water treatment & $80.31^{\mathrm{a}}$ & $10.76^{\mathrm{a}}$ & $126.090^{\mathrm{a}}$ \\
\hline Farmers practice & $76.68^{\mathrm{c}}$ & $9.88^{\mathrm{c}}$ & $96.576^{\mathrm{c}}$ & $21.505^{\mathrm{b}}$ \\
\hline LSD (5\%) & 0.86 & 0.20 & 8.34 & $16.587^{\mathrm{b}}$ \\
CV (\%) & 1.17 & 2.014 & 7.96 & $34.707^{\mathrm{a}}$ \\
\hline
\end{tabular}

Table 3: Effect of seed treatment on yield and yield component of garlic in 2013 production season. *Values connected by the same letter across a column are not statistically different at $5 \%$ significant level.

\begin{tabular}{|c|c|c|c|c|c|}
\hline \multirow[t]{2}{*}{ Treatments } & \multicolumn{2}{|c|}{ Atsela } & \multicolumn{2}{|c|}{ Ayba } & \multirow{2}{*}{$\begin{array}{c}\text { Simret } \\
\text { Total yield }\end{array}$} \\
\hline & Healthy yield qt/ha & Infected yield qt/ha & Healthy yield qt/ha & Infected yield qt/ha & \\
\hline Chemical treatment & $44.49^{a}$ & $13.208^{\mathrm{ab}}$ & $59.71^{c}$ & $23.54^{a}$ & $39.21^{\mathrm{a}}$ \\
\hline Hot water treatment & $57.93^{\mathrm{a}}$ & $9.505 a^{b}$ & $77.46^{\mathrm{b}}$ & $14.50^{\mathrm{b}}$ & $35.47^{\mathrm{ab}}$ \\
\hline Chemical+hot water treatment & $57.44^{\mathrm{a}}$ & $7.547^{\mathrm{b}}$ & $87.08^{\mathrm{a}}$ & $5.500^{\circ}$ & $32.00^{\mathrm{b}}$ \\
\hline Farmers practice & $38.40^{\mathrm{a}}$ & $17.933^{\mathrm{a}}$ & $38.75^{d}$ & $30.08^{\mathrm{a}}$ & $29.99^{b}$ \\
\hline LSD $(5 \%)$ & 22.83 & 9.1372 & 9.19 & 8.7328 & 6.715 \\
\hline CV (\%) & 34.35 & 34.35 & 9.07 & 9.07 & 9.8 \\
\hline
\end{tabular}

Table 4: Effect of seed treatment on yield and yield component of garlic in 2014 production season in Atsela, Ayba and Simret Kebeles. *Values connect by the same letter across a column are not statistically different at $5 \%$ significant level.

by chemical plus hot water treated plots for the value of $57.44 \mathrm{qt} / \mathrm{ha}$ but there was no statistically significant difference among all treatments. Unlike the two Kebeles, incidence of white rot in Simret was $100 \%$ in all farmer's plots and treatments. However, in terms of total yield, the highest (39.21 qt/ha) total yield was recorded from chemical treated plots followed by hot water treated plots for the value of (35.47 qt/ha), although no statistical difference was observed. In contrary, bulb yield was significant lower ( 38.75 and $38.40 \mathrm{Sqt} / \mathrm{ha})$ in the control plots in Ayba and Atsela Kebeles, respectively.

On the other hand, significantly higher white rot infected cloves/ unmarketable yield of 30.08 and $17.93 \mathrm{qt} / \mathrm{ha}$ was found from the control plots in Ayba and Atsela Kebeles, respectively. However, in both Kebeles the lowest white rot infected clove was reported from chemical+hot water treated plots which showed 5.500 and $7.547 \mathrm{qt} / \mathrm{ha}$ unmarketable yield followed by hot water treated plots for the mean yield of 14.50 and $9.505 \mathrm{qt} / \mathrm{ha}$ in Ayba and Atsela Kebeles, respectively. The lowest white rot infected yield recorded from the treated plots indicated that seed treatment and improved management practices like recommended seed rate, recommended fertilizer rate and method of planting have decreased incidence and severity of white rot significantly than the control plots. Zeray and Mohammed [11] also reported that, garlic white rot is highly associated with crop density and planting time of the crop season.

\section{Conclusion}

The production of cash crop like garlic is proved to be income generating activity for farmers, especially for those who have limited cultivated land. Recognizing its importance and total area under garlic production has increased from time to time. In spite of its importance and increased in production, productivity is generally low due to different factors including garlic white rot disease. For minimizing the severity and incidence of this disease on-farm demonstration was conducted for two years under different garlic growing areas of southern Tigray.

The first season demonstration result showed that the highest marketable/healthy yield and low incidence and severity of white rot were recorded from hot water treated plots. In contrary, the lowest marketable yield and the highest infected yield were recorded from control plots. The highest and significantly different plant height and leaf number was also reported from hot water treated plots followed by chemical treated plots. Hot water treatment was also selected and ranked first by participant farmers from the other treatments. Beside its importance on controlling the incidence and severity of the disease white rot and recorded higher marketable yield farmers have preferred the technology by its accessibility, easiness and environmental friendly.

Same result was also observed in the second season, as compare to the other plots, incidence and severity of white rot was very low on hot water plus chemical treated plots but not significantly different with hot water treated plots, respectively. However, in the case of Simret Kebele, even though the incidence of white rot was $100 \%$ in all demonstration plots, comparatively the highest yield was recorded from chemical treated plots. The present result indicated that, white rot 
Citation: Abrha H, Gebretsadik A, Tesfay G, Gebresamuel G (2015) Effect of Seed Treatment on Incidence and Severity of Garlic White Rot (Sclerotium cepivorum Berk) in the Highland Area of South Tigray, North Ethiopia. J Plant Pathol Microb 6: 294. doi:10.4172/2157-7471.1000294

intensity and the efficacy of the treatments were varied from location to location depending on the climatic condition of each Kebele and occurrence of the disease. Therefore, site specific recommendation based on the efficiency of the treatments and environmental condition of each Kebele is crucial.

Therefore, based on the availability, environmental friendliness and farmers preference of the technology, hot water treatment is feasible for all intervention Kebeles and practising of proper agronomic practises (site selection and land preparation, planting at the right time, weeding and hoeing, crop rotation, use of disease free planting material, keeping optimum irrigation interval, harvesting and curing) promote the effectiveness and productivity of the recommended technology.

\section{Acknowledgement}

The study was part of CASCAPE project (Capacity Building for Scaling up of Evidence-Based Best Practices in Agricultural Production in Ethiopia). We thank CASCAPE project for covering the entire cost of the research. We also thank all the research assistants of CASCAPE project working in the experimental sites for their participation in data collection and organization the participation of local farmers. We are grateful to all farmers who have participated in this research for contributing their lands and sharing necessary information. Last but not least we thank Alamata Agriculture Research center pathology researchers Mr. Teklay Abebe and Mr Muruts Legesse who have participated in data collection and technical support.

\section{References}

1. Rubatzky VE, Yamaguchi M ( 1997) World vegetable, In Chapman and hall, (eds.) Principles, production and nutritive values, (2edsn). International Thomson publishing, New York. USA. pp: 843.
2. Central Statistical Authority (2012) Agricultural sample survey 2010/2011. Report on area and production for major crops (Private peasant holding, main season). Statistical Bulletin A.A, Ethiopia.

3. Zeray S (2011) Distribution and Management of Garlic White Rot in Northern Ethiopia: distribution, significance and management of garlic white rot in northern Ethiopia, Ambo University, Ambo Ethiopia.

4. Harnet A, Yibrah G (2015) Evaluating Local Garlic Accessions using Multivariate Analysis Based on agro-morphological Characters in Southern Tigray, Ethiopia. Journal of Natural Sciences Research 5: 211-216.

5. Stewart A, Fullerton RA (1991) Additional studies on the chemical control of onion white rot (Sclerotium cepivorum Berk.) in New Zealand, New Zealand Journal of Crop and Horticultural Science, 19: 129-134.

6. Alamata Agriculture Research Center (2012) Horticulture case team annual problem appraisal report .

7. Tamire Z, Chemeda F, Parshotum K, Sakhuja PK, Ahmed S (2007a)Association of white rot (Sclerotium cepivorum) of garlic with environmental factors and cultural practices in the North Shewa highlands of Ethiopia. Journal of Crop Protection 26: 1566-1573.

8. Davis RM (2010) UC IPM Pest Management Guidelines: onion and garlic.

9. Pinto CMF, Maffía LA, Berger RD, Mizubutiw ES, Casali WD (1998) Progress of white rot on garlic cultivars planted at different times. Plant Disease 82: 1142 1146.

10. Delgadillo SF, Zavaleta-Mejía E, Osada Kawasoe S, Arévalo Valenzuela A, González-Hernández V, et al. (2002) Densidad de inóculo de Sclerotium cepivorum ysu control mediante Tebuconazole enajo (Allium sativum L.). RevistaFitotecnia Mexicana 25: 349-354.

11. Zeray S, Mohammed Y (2012) Survey on Distribution and Significance of Garlic White Rot (Sclerotium cepivorum Berk) in East and southeast Tigray Highlands, Northern Ethiopia. Journal of Applied Science 3: 43-56. 